International Journal of Linguistics, Literature and Translation (IJLLT)

ISSN: 2617-0299 (Online); ISSN: 2708-0099 (Print)

DOI: $10.32996 / \mathrm{jjllt}$

Journal Homepage: https://al-kindipublisher.com/index.php/ijllt

\title{
An investigation of EFL Teachers' Professional Development in Algeria: Practices and Perspectives
}

Dr. Ziani Melouka ${ }^{1 *}$ and Ms. Lahma Saadia²

${ }^{1}$ Faculty of Foreign Languages, University Abdelhamid Ibn Badis, Mostaganem, Algeria

${ }^{2}$ Master student, Faculty of Foreign Languages, University Abdelhamid Ibn Badis, Mostaganem, Algeria

Corresponding Author: Dr. Ziani Melouka, E-mail: ziani.melouka@gmail.com

\section{ARTICLE INFORMATION}

Received: October 02, 2020

Accepted: November 14, 2020

Volume: 3

Issue: 11

DOI: 10.32996/ijltt.2020.3.11.9

\section{KEYWORDS}

Competencies, training, continuing professional development, critical reflection, training programmes.

\section{ABSTRACT}

In English Language Teaching, the complexity of competencies and skills required for maximum achievement calls for a highly structured training programme which caters for a Continuing Professional Development(CPD) of EFL teachers. Hence, it has become more important than ever to involve teachers in the decision making and designing of their CPD programmes. The present paper, then investigates how effective is continuing teacher training to teacher professional development in Algeria. In an attempt to answer this question, an investigation was carried out on a sample of 56 secondary school teachers of English in RELIZANE, Algeria. Using observation and interviews, teachers and teacher trainers were examined on their different standpoints to CPD. The research findings revealed that the participants expressed the same need for a continuing professional development regardless their expertise. But, their perceptions regarding their role in their CPD reflected their dependence on the institutional training programmes. Indeed, it was found that teachers rarely reflected on their education or kept track of their development as teachers.

\section{Introduction}

There is endless debate about how teacher education and training courses should be structured and delivered. Policy-makers in teacher education have shown an interest in how other countries organize their education systems in order to improve their own educational systems in a way that effectively answers the needs of their educational, social and economic contexts. Designing an effective educational programme needs accurate information and feedback about existing and similar programmes, in addition to profound understanding of the special needs of the international and local EFL communities. The evaluation of training programmes is an essential component and a necessary step to ensure that these programmes, in terms of their design and implementation, are directed toward achieving their intended goals. Two main concepts in teacher education are highlighted: teacher training and teacher development.

\section{Literature Review}

In its broad definition, training is a systematic effort planned and managed by an organization to maximize its employees' knowledge and skills so they may perform better in their job. David and Stephen (1989) described training as "A learning experience in that it seeks a relatively permanent change in an individual that will improve his or her ability to perform on the job". Training is also considered as a systematic activity addressed to a specific workforce, focused on a short-term apprenticeship to achieve immediate goals, often, an effective performance at a given task. Michael Jucius (1955) defined training as "a process by which the aptitudes, skills and abilities of employees to perform specific jobs, are increased". According to Flippo (1971), "Training is the act of increasing the knowledge and skills of an employee for doing a particular job" Beach (1980) referred to training as "the organized procedure by which people learn knowledge and/or skills for a definite purpose". Dubashi (1983) defined it as "A process of improving the knowledge skill and attitude of employees to achieve organizational objectives". Drucker (1984) defined training as a "Systematic process of altering the behavior and/or

K C AL-KINDI CENTER

$\mathbf{R}$ D FOR RESEARCH AND $\mathbf{R}$ D DEVELOPMENT Your gateway to world-class research
Published by Al-KindiCenter for Research and Development. Copyright (c) the author(s). This is an open access article under CC BY license (https://creativecommons.org/licenses/by/4.0/) 
attitude of employees in a direction to achieve organizational goals". Training under this light is a job-related, learning how to-do activity which can be realized for all professions and crafts including teaching. However, there is more to teaching than just a craft, hence, teachers need a special kind of training along their teaching careers. Accordingly, teaching has newly gained the conceptualization of a profession, and a great majority of teachers in industrialized nations today are either college or university educated. The quality and form of the training, however, varies from one context to another. Modern teacher training is the professional preparation of teachers, usually through formal courses and practice teaching. Training involves the ability to perform in the classroom according to certain predetermined standards. The content of training programmes is usually decided upon by experts and is often delivered in formal, standard training formats aimed at answering certain goals, among which: Learning how to use effective strategies to open a lesson.

a. Adapting the textbook to match the class objectives and needs

b. Learning different types of assessment and how to realize them

c. Using effective questioning techniques

d. Using classroom aids and resources (e.g. audiovisuals)

e. Techniques for giving learners feedback on performance

It is important to distinguish here between two main types of training for teachers: pre-service and in-service.

\subsection{Pre-Service Training}

Pre-service teacher education (PSTE) programs are the first form of professional education that prospective teachers have to complete before they can join the teaching profession. These programs typically consist of theoretical knowledge about teaching and a field-based practice experience often referred to as practicum. The quality of training provided through PSTE programs affects teacher' practice, effectiveness, and career commitment (Eren \& Tezel, 2010; Liang, Ebenezer, \& Yost, 2010; Roness, 2010). Classroom practice, on the other hand, can reveal a good deal the quality of both teaching and learning which depends on and reflects the quality of PSTE programs. The relation between student achievement and teaching quality depends on the quality of PSTE programs. Developing and preserving high-quality of PSTE programs can go a long way in the success of development activities that aim to improve the quality of teaching and learning for all children (Nye, Konstantopoulos, \& Hedges, 2004; Rivkin, Hanushek, \& Kain, 2005; 1996; Verspoor, 1989). PSTE programs are part of a whole which specialists in the field of education call a continuum of learning to teach. The pre-service programs are also considered foundational building blocks for careerlong professional development (Darling-Hammond, 1996). In most developing countries, the PSTE programs are regulated by the governments and implemented by institutions accredited by the ministries of education for licensing and/or certification of teachers. Because teacher certification policies and standards vary from one country to the other, PSTE programs also vary in content and duration, as well as in the nature of teaching practice. Although pre-service teaching appears to most people as the first stage of a teaching career, learning to teach begins much earlier in an informal phase. This first phase of the continuum is often referred to as the apprenticeship of observation, the period during which a student is observing his or her teachers, be it consciously or unconsciously. The second stage is the formal PSTE, that is the period when a prospective teacher participates in and completes a formal teacher preparation program enabling him or her to acquire the knowledge (both subject matter and pedagogy), skills, and attitudes to be an effective teacher. PSTE is followed by induction, which refers to the first year of a teache's career.

\subsection{In-Service Training}

After completing their initial teacher-education program including the practicum, teachers who start teaching are now more than any time before involved in a learning to teach process which Doyle (1977) defines as "learning the texture of the classroom and the sets of behaviours congruent with the environmental demands of the setting". "Those education and training activities engaged in by secondary and primary school teachers and principals, following their initial professional certification, and intended mainly or exclusively to improve their professional knowledge, skills, and attitudes in order that they can educate children more effectively." (Day, 1997: p.46). Day in this definition is referring to two phases of training: Pre-Service and In Service. He also points to the fact that initial training is not enough for an effective teaching practice. Teachers change and develop at each stage of their professional lives, therefore, it is important that they consistently update and improve both their pedagogical skills and knowledge about their subject matter. In other words, the continuity and effectiveness of teacher professional development needs to be systematically implemented in in-service training programmes. Day refers to in-service training as continuing professional development which goes beyond the immediate teaching and learning environment and where "the personal and long-term professional needs of the teacher are legitimated." (Day, 1997: p.40) According to Day, in order for the continuing professional development to be effective, it should go beyond the classroom practice to affect the teacher as a person, too. During their in-service training, teachers should be taught to take responsibility of their continuing professional development by emphasizing reflective practice and 
action research, this way teachers will be the trainees and their own trainers at the same time. The practicum in its expectation is an effective learning how-to-teach experience where pre-service teachers have sufficient time and opportunity to apply what they have learned (Darling-Hammond, 2006). Applying their knowledge and skills in a real life context enables pre-service teachers to have authentic experiences that facilitate deep learning (Kolb, 1994). Student teachers who participate in a practicum are better able to understand theory, apply concepts they are learning in their coursework, and support student learning (Koerner, Rust, \& Baumgartner, 2002).

\subsection{Teacher Continuing Professional Development}

Teacher development is all types of activities and experiences of formal and informal education/learning that teachers undertake. It is a career-long process with the objective of motivating in-service teachers to reflect on their teaching, update and broaden their professional knowledge. It aims mainly at helping teachers not only improve their teaching skills, but also engage in meaningful professional learning. Continuing Professional Development (CPD) comes in different forms, CPD may include activities such as: in-service training courses, peer-observation, reflection in practice, attending conferences, engaging in digital and e-learning, networking and last but not least conducting action research. Teacher development is planned activities which focus on increasing and enlarging the capabilities of teachers so that they can successfully handle greater responsibilities and challenges. Obisi (1996) stated that the concepts of training and development are used interchangeably. However, they can be differentiated one from the other. Training is for specific job purpose while development goes beyond specifics. Development covers not only Aprenticeship of Observation Pre-Service Teacher Education Induction Continuing Professional Development those activities which improve job performance, but also those which bring about growth of personality. It generally refers to general growth not focused on a specific job. It serves a longerterm goal and seeks to facilitate teachers understanding of teaching and of themselves as teachers. Teacher development often involves a great deal of self-reflection through which teachers better analyze and understand teaching as a holistic process and of themselves as part of this process. The following are examples of goals from a development perspective:

a. Understanding how the process of second language development occurs

b. Understanding how teachers" roles change according to the kind of learners they are

c. teaching Understanding the kinds of decision making that occur in the classroom

d. Reviewing and updating teacher' own theories and principles of language teaching

e. Developing an understanding of different styles of teaching

f. Determining learner' perceptions of classroom activities

g. Learning to teach is an ongoing process spread over on's entire teaching career through continuing professional development (CPD).

CPD refers to teacher participation in in-service training or professional opportunities to update and upgrade knowledge, skills, and qualifications. CPD also serves to enhance teacher' professional identity. In-service teacher training is another term widely used for the training provided to practicing teachers throughout their careers instead of CPD. This final stage is marked by the largest arrow, for in perfect circumstances, teachers would periodically and regularly receive professional training throughout their careers. The role of a trainer or supervisor is very important in training. All development is selfdevelopment and the teacher has to be internally motivated and autonomous. The content of the training is specific job related (subject matter).

\subsection{Activities for Teacher Professional Development}

A variety of methods and activities can be applied both formally and informally for teacher professional development, some of which can be carried out at the individual level, some involve working with a colleague, some are group-based, and others respond to the teache's institutional directive.Some of these activities can be carried at more than one form. We will try to address some of these activities with more details:
a. Individual One-to-one Group-based Institutional Selfmonitoring
b. Journal writing
c. incidents Teaching
d. portfolios
e. Action research
f. Peer coaching
g. Peer observation
h. Critical friendships
i. Critical incidents 
j. Case studies

k. Journal writing

I. Teacher support groups

m. Workshops

n. Conferences \& Seminars

\section{Methodolgy}

To collect data for our research, we adopted a qualitative approach. We administrated interviews for Secondary School teachers of English of Relizane, Algeria and observation for a seminar for the second district of inspection in Relizane. During the interviews it became necessary that another interview with the head of the service of inspection in the administration of education in Relizane would be useful to answer and clarify some issues that were left unveiled after inspectors withdrew from the interviews. Participants in this study consist of secondary school teachers of English of Relizane from districts 1 and 2 and the inspector of district 2. Six teachers from six different high schools were chosen to participate in the interviews. There were three teachers from each district, ranging from novice, principle to trainer. Those teachers were chosen to represent a population of 190 teachers. A second sample, which concerns administrators this time, the head of the service of inspection in the administration of education of Relizane, has been selected to enrich the study with information that cannot be gathered from teachers, and to confirm or falsify some claims of both teachers and inspectors in regards to the management of teacher training in terms of finance and human resources.

This research is mainly descriptive using the qualitative approach to gather data. The descriptive method enables us to analyze the reality of CPD in Algeria and identify the impediments for its realization and seek ways to create a reliable model of training based on the Algerian current context. Data Gathering Tools suggests that different data collection methods allow researchers to focus on different aspects of a question. Richards (2003).

The interview has been designed for Secondary School teachers of English of Relizane during the school year 2018-2019, the common feature that distinguished the sample of teachers was that they all graduated from University. The interviews took period of more than 2 months, they were conducted from March to May, 2019. This period of time was chosen in order to cover activities over two seminars in order to give a more representative picture of the training process during the current school year and to ensure a manageable period for teacher' recall. Some interviews were conducted in the seminar centers and some in each teacher's school. Six secondary school English teachers were interviewed individually in addition to two directors of training administrations, the medium was English for the formers and Arabic for the latters. Each interview lasted between 10 to 20 minutes. Three interviews were recorded with the respondent' permission and some notes were taken during and following the other interviews. All teachers were asked the same questions, the flexibility of the semi-structured interviews format enabled the researcher to probe beyond the teacher' initial answers to gain further clarification or elaboration, and a greater depth of information. The interview contains 11 questions designed according to specific aims and purposes. They included some direct questions like :(How long have you been teaching? What qualifications do you have? What subjects related to teaching did you have and for how long? How did you become a teacher?) At the same time, the researcher intentionally asked indirect questions in order to know if Secondary English teachers of Relizane are aware of the concept of Continuing Professional Development (e.g.: What does the term CPD mean to you? Could you describe your inservice training? Apart from seminars, what other forms of training do you receive?)

All interviewed teachers said they had a BA of English literature. During the interview, T1 mentioned that many of her colleagues from the same generation had a BA of translation Arabic-French-English which was quite interesting to the present research. Question 3: What subjects related to teaching did you have at University and for how long? In this phase of the interview, the researcher was investigating on the preservice training of ELTs at University. The answers revealed that teachers were actually not taught how to teach at this stage, i.e. before graduation. In response to this question, T1 said teachers of that graduation year had absolutely no subject related to teaching, T2 could not remember whether they ever had any, while the remaining teachers said they had TEFOL during graduation year. Interestingly, T5 and 6 said they had a Pedagogy course for one semester during graduation year and that it was taught to them in French with which they were struggling. Question 4: Can you still relate to them in your teaching practice? Where they useful to you as a teacher? In this question the researcher intended to find a match between theory and practice, the intentions and applications from the standpoint of the Algerian Ministry of Higher Education and the reality from a teacher's perspective. Teachers 3, 5 and 6 said the few lectures they had in TEOFL and Pedagogy in the case of T5 and T6 were of little significance. T4 explained that further by saying that that one year was not enough, besides, there was no practice for what we were taught in that subject, 
nevertheless, she said that some of TEOFL lectures were useful during her first experience in teaching, mainly, according to her, because the teacher at that time was very competent. T6 made a good point by saying that they forgot the few information about teaching they learnt in those subjects because they spent some time before they could find a job in teaching. Concerning their qualifications, some of the interviewees said they passed the national contest for teaching, this was a three-hour exam in Pedagogy and one hour in general culture done in L1 (Arabic). Then, the researcher tries to highlight the importance of preservice training of the teache's educational life and find the missing link in the case of the Algerian ELTs. T1 said she had no pre-service training. In her own words "Nothing at all, from two years of home routine straight to the classroom". It was the same case for T2 except that he got hired few months after graduation. It is worth noting that T2-6 didn"t understand what pre-service training meant. After explaining it, they all said they had none. T3-6 were called to start teaching right after results of the contest were announced.Then, it was important to unveil the intervieewees' first teaching experience (Theory vs Reality). The purpose from asking this question was to compare the theory of preservice training if it ever occurred for novice teachers and their first experience in teaching practice. T1 replied to that question by stating that she had never intended to work as a teacher but her first day in the classroom was amazing, she loved the pupils. 12 said that he did't know what to do and that during the first two years in the classroom he only learned how to teach the content of the textbook. T3 said she panicked and did't want to go to the classroom again. T4 said that it was hard and that she did not know how to deal with the pupils. T5 and T6 said it was not something they wished to remember and T6 added that she felt he was't meant for teaching.

The following question concerns the teachers' in-service training in terms of efficiency and frequency. To this question, the researcher was trying to find out the forms of training EFLs were receiving and its quality. Apparently the only form was seminars. T1 mentioned one regional training she had in another city with three inspectors, it was really fruitful she said and apart from that one, they are all the same. She added that she did't get anything practical from them. T2, T3, T5 and T6 said they only know about seminars and that they take place once to three times a year. T4 said they generally have one to two seminars a year, she talked about one workshop by an inspector that was 8 years ago. It was a two-day seminar, she said, and she learnt a lot from it. The researcher, then wants to find out if there are other other forms of training ,both institutional and individual that Algerian ELTs are involved in and whether they are aware of their existence. After thinking for a while, T1 replied with "Coordination with colleagues whithin my school and sometimes in other schools" T2-6 all said that seminars were the only form or training they received. T4 added that she may occasionally make some research on topics she needs for her classroom, basically lesson-related. Then, we tried to know whether the intervieewees knew the term CPD or not.The purpose from asking such a question was to see to what extent the Algerian EFLs are updated in terms of teacher education. After giving the full form of the abbreviation, all my interviewed teachers were still not able to recognize the concept of CPD. T3 said he did't think we had such a thing in the Algerian educational system.

The second research tool, observation was carried during a one-day seminar that took place on April 30, 2019, at Qabbati secondary school, Oued Rhiou, $52 \mathrm{~km}$ from Relizane center. The participants were 50 teachers from the second district of inspection in Relizane, they represented 20 secondary schools. The researcher chose to make an observation of a seminar so as to compare the data gathered during the observation with that of the interviews, for "what people do may differ from what they say they do" Robson (2002), and observation's potential is to provide researchers with naturally occurring behaviour. The seminar started at $9 \mathrm{am}$. The invited teachers where all teachers of the second district. The objective of the seminar was to share with teachers the guide of exam typology designed by the Ministry of Education in 2017. The secondary school was the oldest in the town which could be noticed from its construction. The seminar was held in an amphitheater with bench chairs which allowed for only one seating arrangement. The materials used were a projector and handouts. The inspector started by greeting the teachers and explaining the objective of the seminar. This went on for $30 \mathrm{mns}$ during which he informed teachers that he had to be downtown before 2:30 pm in his words "we have to finish very quickly". At 9:34 the inspector asked teachers to form 6 groups and take turns in reading out loud from six handouts he passed through them. The number of the printed copies was only enough to give each school one copy. This went on till 11:00 during which he would occasionally stop the teacher who was reading to explain the instructions from the guide. Once explaining the guide finished, the teachers and inspector took a coffee break in the same amphitheater for $15 \mathrm{mns}$. The teachers resumed work right after the break. The inspector asked them to use the texts they brought with them to design an exam paper according to the guide explained. Teachers were confused because many brought texts on the same topic. This problem was solved by assigning a theme to each group. This way only one text was used in each group. The size of the groups ranged from 7 to 11 teachers per group. The bench chairs in the amphitheater were not practical for group work. Because teachers could only sit in one line, one beside the other. And with the large size of each group, it was difficult for members of the same group to share the same paper, be it the handouts or the text paper. Some group members used their smart phones to take a photo of the text so they can sit comfortably and do the task, however that meant working individually. The inspector did't allocate time for this 
task so it went from 11 to 11:49. During this time the inspector would leave the amphitheater and leave the teachers alone. Teachers were using Arabic alone during their group discussions and interaction. It became more and more noisy so the researcher had to get closer to each group to see how they were going about the task. In most groups it was noticed that teachers didn't assign roles within the same group. There was a dominant member in each group who was reading the text out loud to the rest of the members. This can explain part of the noise. Some teachers were working individually while others were not involved and started small talks that deviated in content from the objective of the seminar. At 11:40 the inspected asked the groups to get ready to present in $5 \mathrm{mn}$. Presentations started at 11:49 with the majority of the groups not finished their task. One member from each group faced the rest of the groups and read their work. The inspector interrupted now and then to correct pronunciation mistakes. All six groups had presented by 12:46 when the school headmaster announced that lunch was ready. The inspector invited the teachers to have lunch and wished them a nice day.

\section{Discussion of the findings}

Once Algerian graduates with a BA degree at English Literature pass the national contest organized by the Ministry of Higher Education, they become legible to teach. The contest is based on specific criteria that include written and spoken exams. The latter was introduced since Algeria adopted the Communicative approach in 2000 in an attempt to adapt with the universal changes that occurred in the field of English language teaching (Benmati, 2008). Therefore, the focus of the teaching qualifying exam is built upon the communicative approach principles. The novice teachers then spend two years in service as candidates for the qualifying exam. This explains the interviewees claim of not having received any kind of pre-service after their graduation. When the researcher asked the head of the administration of inspection in Relizane about pre-service training for candidates who pass the national contest, he replied that the Ministry of Education issued training for this category only in 2012. This means all teachers who started teaching before 2012 had no pre-service training. Teacher training in Algeria is the 'core dilemma' of the Algerian education as Ghedjghoudj (2002) describes it. As most of the interviewees revealed, what they learned at university was of little significance, if any, to their teaching practice. Benmati (2008) went further to highlight the high school curriculum mismatch with the university curricula. This only demonstrates how deep rooted the problem of Algerian ELT preparation is. Another issue was highlighted during the observation and the interviews was the low level of professionalism among both teachers and the inspector. Both inspector and teachers demonstrated weak time management and group work skills. The inspector used $3 \mathrm{~h} 46 \mathrm{mns}$ without asking for any feedback from the part of the trainees. He asked them to work in groups with a large size that did not allow for a good interaction, besides, the bench chairs did not help with the seating arrangement suitable for group work. On their side, teachers used 49mns without completing the task assigned to them and they were lost in terms of organizing their groups and group work. There was also a weak interaction between teachers and the inspector which was mainly due to the teacher-centered approach used by the inspector, who could clearly not control his talking time. The 21st century skills are important in shaping future professionals Maraf (2012). Thus, teacher trainings should be based on the implementation of the 21st century skills. Maraf believes that those trainings enable teachers to be ready for the unexpected behaviors of their students and the creative methods they may initiate in class. They also described seminars as being more theoretical than practical some even described them as a mere waste of time. Another point in this respect is the decision making process that takes place in two different levels with weak coordination. Teachers sit for a contest prepared by the Ministry of Education to answer a paper prepared by the Ministry of Higher Education. Those who pass would work under the terms of the Ministry of Education and rely on their first teaching experience on the very few teaching-related knowledge they received at university. The core issue of divided responsibilities but shared mission makes coordination and collaboration between the two ministries almost impossible. The Algerian teacher is a product of both ministries, however, it is with the Ministry of Education that his career will be influenced the most. Thus, the designing of training programs should be initiated by the Ministry of Education in collaboration with the Ministry of Higher Education. CPD is a concept that is not yet well internalized by the Algerian EFL teacher. On the other hand, teachers'dependency on institutional initiatives for training and development resulted in a passive kind of teachers who are so unwilling to engage in any further teacher learning activities. The fact that all interviewees were holders of a BA of English, literature demonstrates their reluctance in taking any further academic course. Moreover, both interviews and observation revealed that there was no initiative from teachers towards their professional development. Another point to reflect on concerning the professional relation between teachers from the same district and even the same school is the absence of coordination. Most teachers were referring to one the other by 'mis' or sir' using no names. Besides, teachers from the same schools were noticed to be sitting in separate groups. This observation confirmed the information derived from the interview regarding teachers'coordination. Last but not least is the rapport between the trainees and the trainer ; it was an interesting issue that was unveiled during both interviews and observation. Two of the interviewees stated that the only workshops they do recall are those delivered by remarkable inspectors. One of them used the description'very competent' to refer to the inspector in question, whereas the other used a more interesting description: "I still remember 
them even after 30 years because those were human". In this context, the word human is quite ambiguous, however, it is indeed the human relationship that was missing in the interaction between the inspector and the trainees.

\section{Conclusion}

In the light of the results discussed above, teacher CPD should start from teachers themselves. Teachers, thus, should be involved in the designing and delivery of their CPD. Teachers should also reflect on both their education and practice. These two need to be updated constantly to meet the new requirements and needs of the teacher first then the classroom. Teachers are reluctant to take any further step in their education programme; however, this can take many forms apart from academic courses. At the institutional level, it is highly recommended to open new instituted at the regional level for teacher preparation. When ENS (École Normale Supérieure) cannot provide enough teachers to cover the need for teachers of English, the ministry of education opens the national competition for University graduates with a BA of English Literature. Those are later sent to a "swim or sink" situation where the rare few survive the professional shock.

Therefore, it is high time new institutions specialized for training are opened to supply middle and high school with the sufficient number of qualified teachers. Moreover, the ministry of education ought to encourage teachers to take master courses in subjects such as didactics, applied linguistics and educational psychology. Those courses can prepare qualified inservice teachers who would directly apply what they learn in the classroom and more importantly, share it with their colleagues. This is rather a less costly alternative for cascade models of teacher training. We do not have to send a few teachers to seek expertise from foreign countries with a high cost and uncertain results. Considering the large size of Algeria, cascade models can only work if they are initiated at the national level with local experts. The fusion of the two ministries on the other hand, does not necessarily require having one ministry instead of two. However, the idea of having one department with two divided missions but one common objective may improve teacher training in Algeria. Collaboration between the two ministries is also a highly required step in the development of CPD programmes. Instead of relying mainly on Inspectors, the Ministry of Education can make use of the competencies at the departments of English or even of other subjects related to teaching regardless the language. University teachers of didactics, pedagogy, applied linguistics and educational psychology should all be involved and consulted in the designing but also delivery of CPD programmes. Teachers are thrown in at the deep end with on the job guidance from their inspector. What they need is basic training before they start. Things like child psychology, lesson planning, error analysis, overview of different methodologies, Basic guidance on Special Educational Needs (SEN) and how to identify conditions such as dyslexia, teaching mixed ability, classroom management etc. Ideally, they should do a one-year training course which includes observed teaching practice. This may not be possible due to cost and the size of the country, but a two-month stage over the summer with access to online materials should be possible and would be much better than nothing. The questions asked time and again on the AATE Facebook page are often basic and show a lack of any real training. Many inspectors also have had to learn the hard way and some have developed "their own methods' and may be resistant to change or new ideas. It also can be seen as a threat to their expertise and social standing, so requires some sensitivity. Cascade training could be used to reinforce their standing. Those can serve as teachers under prominent educational systems in foreign countries and come back to use the expertise gained to train teacher trainers, who in their tern train trainee teachers. There should be a fixed programme which is ticked off and standard for everyone- like a matrix, but then, there could be optional topics and sessions for those who want to specialize or learn more about a certain topic. That way we can see the basic training and the CPD built on top of it. For just as training should go according to layers of expertise, it should also allow personalized learning for teachers with different pedagogical needs. One of the key things to remember about the Algerian context, something which people forget especially trainers coming from abroad, is that English teaching in state schools is part of the state school system. It is not about teaching English in a private language school which can make its own rules. It has to fit into a system which teaches other subjects and has set protocols and procedures. We can see grassroots teachers crying out for change, but this needs to win over decision makers at Ministry level. 


\section{References}

[1] Baldwin, T. T., \& Ford, J. K. (1988). Transfer of training: A review and directions for future research. Personnel psychology, 41(1), 63105.

[2] Burgess, E. M. (2014). Leading quality teaching: an exploratory case study of two improving Australian schools (Doctoral thesis), University of Tasmania.

[3] Carroll, A. B. (1999). Corporate social responsibility: Evolution of a definitional construct. Business \& society, 38(3), $268-295$.

[4] Combs, J., Liu, Y., Hall, A., \& Ketchen, D. (2006). How much do high-performance work practices matter? A meta-analysis of their effects on organizational performance. Personnel psychology, 59(3), 501-528.

[5] Darling-Hammond, L. (2006). Constructing 21st-century teacher education. Journal of teacher education, 57(3), 300-314.

[6] Darling-Hammond, L., \& Bransford, J. (Eds.). (2007). Preparing teachers for a changing world: What teachers should learn and be able to do. John Wiley \& Sons. Du Plessis, J., \& Muzaffar, I. (2010). Professional Learning Communities in the Teachers' College: A Resource for Teacher Educators. EQUIP1.

[7] Doyle, W. (1977). Learning the Classroom Environment: An Ecological Analysis .Texas State University

[8] Eren, A., \& Tezel, K. V. (2010). Factors influencing teaching choice, professional plans about teaching, and future time perspective: A mediational analysis. Teaching and Teacher Education, 26(7), 1416-28.

[9] Gordon, R. J., Kane, T. J., \& Staiger, D. (2006). Identifying effective teachers using performance on the job (pp. 2006-01). Washington, DC: Brookings Institution.

[10] Kaundal, R. (2016). Impact of Training and Development on Job Performance of Employees: A Study of SJVN LTD.

[11] Lange, S., \& Lange, S. (2016). Achieving Teaching Quality in Sub-Saharan Africa. Springer Fachmedien Wiesbaden

[12] Mathur, K. M. (1987). Human Resource Development in Administration. Indian Journal of Public Administration, 33(2), $210-241$.

[13] Jucius, M. (1955). Personnel Management - Richard D. Irwin Inc., Hanewood, U.S.A - pp. 142

[14] Obisi,C (2001). Employee Development, Issues and Dimensions. Unical Journal of public Administrator .Sept Vol. 1

[15] Paine, L., Bloemeke, S., \& Aydarova, O. (2016). Teachers and teaching in the context of globalization. Handbook of research on teaching, 717-786.

[16] Richards, J. C., Gallo, P. B., \& Renandya, W. A. (2001). Exploring teachers'beliefs and the processes of change. PAC journal, 1(1), 41-58.

[17] Richards, J. C., \& Farrell, T. S. C. (2005). Professional development for language teachers: Strategies for teacher learning. Ernst Klett Sprachen.

[18] Riege, A. M. (2003). Validity and reliability tests in case study research: a literature review with "hands-on" applications for each research phase. Qualitative market research: An international journal, 6(2), 75-86.

[19] Sazegar, Z., \& Motallebzadeh, K. (2018). Investigating EFL Teachers' Perspectives on Teachers' Professional Development and Barriers of Professional Development. Humanising Language Teaching, 20(2).

[20] Tucker, P. D., Stronge, J. H., Gareis, C. R., \& Beers, C. S. (2003). The efficacy of portfolios for teacher evaluation and professional development: Do they make a difference? Educational administration quarterly, 39(5), 572-602. 